
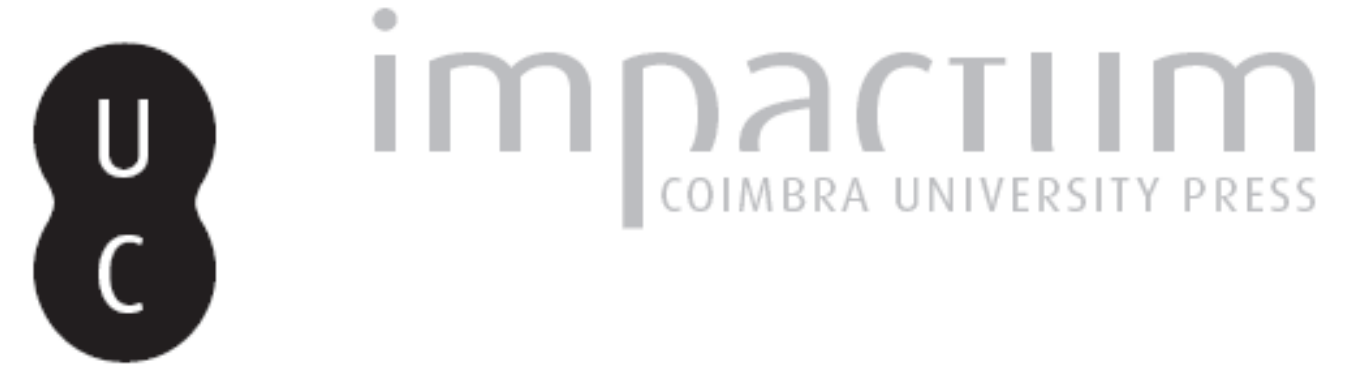

\title{
[Recensão a] STEPHANIE LYNN BUDIN (2016), Artemis. (Gods and Heroes of the Ancient World)
}

Autor(es): $\quad$ Magalhães, José Malheiro

Publicado por: Centro de História da Universidade de Lisboa

URL persistente:

URI:http://hdl.handle.net/10316.2/41164

DOI:

DOI:https://doi.org/10.14195/0871-9527_25_18

Accessed : $\quad$ 26-Apr-2023 13:48:18

A navegação consulta e descarregamento dos títulos inseridos nas Bibliotecas Digitais UC Digitalis, UC Pombalina e UC Impactum, pressupõem a aceitação plena e sem reservas dos Termos e Condições de Uso destas Bibliotecas Digitais, disponíveis em https://digitalis.uc.pt/pt-pt/termos.

Conforme exposto nos referidos Termos e Condições de Uso, o descarregamento de títulos de acesso restrito requer uma licença válida de autorização devendo o utilizador aceder ao(s) documento(s) a partir de um endereço de IP da instituição detentora da supramencionada licença.

Ao utilizador é apenas permitido o descarregamento para uso pessoal, pelo que o emprego do(s) título(s) descarregado(s) para outro fim, designadamente comercial, carece de autorização do respetivo autor ou editor da obra.

Na medida em que todas as obras da UC Digitalis se encontram protegidas pelo Código do Direito de Autor e Direitos Conexos e demais legislação aplicável, toda a cópia, parcial ou total, deste documento, nos casos em que é legalmente admitida, deverá conter ou fazer-se acompanhar por este aviso.

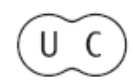



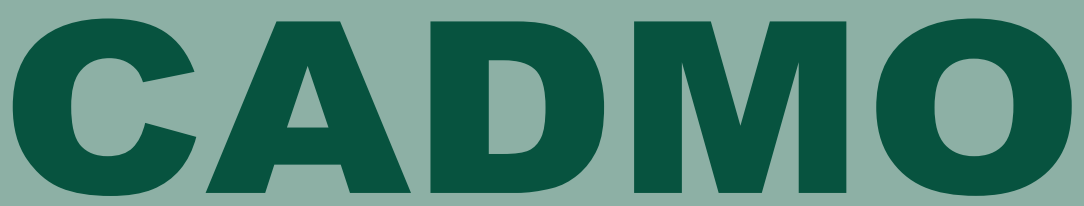

Revista de História Antiga

\author{
Centro de História \\ da Universidade de Lisboa
}

\title{
25
}

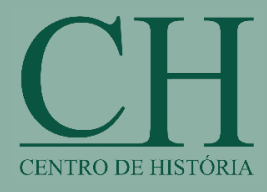

47人

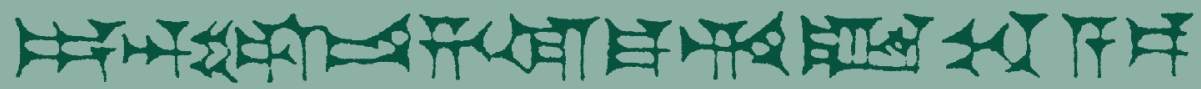

MHNIN AEI $\triangle \mathrm{E} \Theta \mathrm{EA} \Pi \mathrm{\Pi H} \Lambda \mathrm{HIA} \Delta \mathrm{E} \Omega$ 
O capítulo número cinco versa sobre a interacção entre Apolo e a cidade. O A. debate a presença do deus na vida dos cidadãos, em especial na dos jovens que deixam a infância e ingressam na vida adulta, sendo esse um momento assinalado, simbolicamente, pelo corte de uma madeixa de cabelo que será, posteriormente, oferecida a Apolo. Sucintamente, Fritz Graf retrata as interacções, vivências e influências do deus jovem na sociedade grega da Antiguidade.

No capítulo seguinte, o sexto, é tratada a problemática da origem dos rituais e da função dos mitos apolíneos na sociedade grega. Fritz Graf introduz o leitor nas linhas de investigação que, de alguma forma, tentam explicar a evolução de termos e adjectivos que estão na base do fenómeno religioso em torno de Apolo. Ao longo deste capítulo, verificamos que a análise de Graf reflecte a preocupação do A. em provar a antiguidade do deus.

O último capítulo trata o destino de Apolo no pensamento das sociedades posteriores, não tendo escapado ao estudo a apropriação de Apolo pelo cristianismo, bem como a frequente representação do deus na arte ocidental. Completa o estudo uma breve análise dicotómica Apolo/Dioniso.

Ao longo do volume, Fritz Graf dá a conhecer, a um público alargado, a importância de Apolo nos mitos e no culto das sociedades da Antiguidade.

O A. utiliza as fontes para fundamentar a análise elaborada e encaminhar o leitor na compreensão da densa imagem de Apolo.

A obra revela-se de enorme importância e utilidade para quem se interessa pela Antiguidade Clássica, mas que não pretenda envolver-se em excessiva erudição literária. Mas este estudo é simultaneamente uma excelente ferramenta para os estudantes de religião grega.

Como ponto negativo, salientamos a falta de interacção entre as imagens e o texto, limitando-se as mesmas a servirem de ilustração, tout court.

Isabel Costa Santos

Universidade de Lisboa

STEPHANIE LYNN BUDIN (2016), Artemis. (Gods and Heroes of the Ancient World), London/New York, Routledge, xi+184 pp. ISBN 978-0-415-72541-5 (85£).

Stephanie Budin's Artemis is the most recent addition to the Routledge Gods and Heroes of the Ancient World series. When considering a "biography" of Artemis there are certain alarms that start ringing: the goddess does not have a strong presence in ancient literary sources, is almost absent from the Homeric texts and has no relevance in tragedy, with the exception of Euripides' Hippolytus. This pattern is also visible in modern scholarship where Artemis is considerably outshined by the study of several other divinities, 
such as Zeus, Athena, Dionysus or even her twin brother Apollo. Considering her lack of predominance in ancient literary sources we could be under the impression that Artemis is a secondary figure in the Greek pantheon, however Budin very successfully shows how wrong that conception is. Acknowledging the literary sources limitations, Budin traces Artemis' path through a thorough analysis of the archeological and iconographical sources, brilliantly showing the early presence of the goddess in the Greek world, her wide geographical expansion and relevance in the daily life of the ancient Greeks, providing a deep analysis of the rich cult variety of the goddess.

Artemis follows the same pattern of organization and the main aim of the series: a book that is approachable by Classics undergraduate students and the general public. The book also follows the same organization of the other volumes of the Gods and Heroes series, divided in three major sections: an introductory chapter where Budin successfully untangles the roots of the goddess, dwelling through the ancient Minoan divinities and Near-Eastern influences; a main part where she addresses several key themes, that I will very briefly approach, and a final chapter on the reception of Artemis since antiquity.

In "The Childhood and Perpetual virginity of Artemis", the author addresses Artemis' eternal youth, perpetually remaining in a state of adolescence that combined with her eternal virginal votes makes her the mythological conception of one of the most important transition phases of a woman's life: the transition between childhood and married life, the loss of virginity and childbearing. In "Artemis of the Wilds", Budin not only explores the most famous aspect of Artemis, the goddess of the hunt, but also the general connection between goddess and nature and the sacrificial particularities of her cult. In this chapter the reader is faced with some of the least known characteristics of Artemis, such as the relation between her cult and the water element and the goddess's role in war. In "Artemis and Children" the author dwells through a range of sources that show that the connection between Artemis and children, although generally recognized as kourotrophos (nurturer of children), is far more negative that what is usually considered. In "Artemis and Woman" Budin explores the role the goddess plays in the transition between girl and woman, giving insight to the specific phases: from girl to bride and from bride to mother. In the sixth chapter, "Artemis as Goddess of Plague and Cruelty", Budin deals with the evil side that is transversal to almost every god of the Greek pantheon. The author promotes a close insight to the level of cruelty present in several cultic practices such as the human sacrifice rumors and violent cultic developments during Roman time. In "Some underappreciated aspects of Artemis", one of the most original chapters of the entire Gods and Heroes series, the author explores the relevant role of Artemis as a goddess of the city, opposing to her widely known connection to nature, and the development of her practically unknown function as freer of slaves. 
"Artemis Afterwards" follows the same pattern of the other books of the series, however Budin's approach to cinema, and specially the connection between antiquity and a blockbuster such as The Hunger Games, is a refreshing view compared to the previous editions. Although the modern literature reception that the other authors usually address in this chapter is particularly interesting, the books in this collection generally do not make references to the reception of classical topics in recent cinematic productions or recent literature. The importance of this kind of study is increasing inside academia, as it can be perceived by the three panels on classical reception in the last Classical Association Conference in Edinburgh, one concerning sci-fi literature, another devoted to cinema and a round table session on crime fiction and ancient Rome. It is a valid path to show how the ancient world is very much alive today, and a sensible option to approach new generations of students and a more general audience. Budin's use of current language, fresh approach and careful presentation of the sources (providing fifteen images) perfectly fits the series' aim, but simultaneously is a great piece of scholarship on a topic that lacked a reference book.

José Malheiro Magalhães

Universidade de Lisboa, Centro de História

RUBY BLONDELL (2015), Helen of Troy: Beauty, Myth, Devastation. Oxford, Oxford University Press, 312 pp. ISBN 978-0-190-26353-9 (£20.99).

A obra de R. Blondell pretende estudar sobretudo a imagem de Helena na história da Cultura Grega, mas não somente. Este livro foca-se também em todos aqueles que, de uma forma ou de outra, estiveram presentes na Guerra de Tróia e na vida de Helena, e.g., Menelau, Páris, Heitor e Penélope. Para isso, a autora divide a obra em treze capítulos, focando-se não apenas em obras gerais, mas também em fontes específicas sobre o assunto, como a Odisseia e a llíada, havendo ainda referências a Hesíodo, Górgias, Heródoto, Eurípides e Isócrates. No décimo terceiro capítulo, Blondell faz referência a algumas obras contemporâneas sobre Helena, nomeadamente na arte, na literatura e no cinema.

Nos primeiros três capítulos do livro, contudo, a autora foca-se no mito de Helena, apresentando-a, segundo uma das tradições, como filha de Zeus e de Leda e, segundo outra das tradições, como filha de Némesis. É de salientar que em ambas as tradições o pai de Helena é sempre Zeus. Nestes capítulos, Blondell compara Helena a Pandora e a Afrodite, especialmente no que respeita à questão da beleza fatal, termo aliás usado pela própria autora. Esta é também uma das questões centrais que esta especialista pretende transmitir, comparando Helena a essas outras duas personagens 